\title{
Description of new Muricidae (Mollusca: Gastropoda) collected during the ATIMO VATAE expedition to Madagascar "Deep South"
}

\author{
Roland HOUART \\ Research associate, Institut royal des Sciences naturelles de Belgique, \\ rue Vautier 29, B-1000 Bruxelles (Belgium) \\ roland.houart@skynet.be \\ Virginie HÉROS \\ Muséum national d'Histoire naturelle, \\ Département Systématique \& Évolution, \\ case postale 51, 57 rue Cuvier, F-75231 Paris cedex 05 (France) \\ malaco@mnhn.fr
}

KEY WORDS

Mollusca,

Gastropoda,

Muricidae,

Madagascar "Deep

South",

new species.

MOTS CLÉS

Mollusques,

Gastéropodes, Muricidae,

"Grand Sud " malgache,
Houart R. \& Héros V. 2013. - Description of new Muricidae (Mollusca: Gastropoda) collected during the ATIMO VATAE expedition to Madagascar "Deep South". Zoosystema 35 (4): 503-523. http://dx.doi.org/10.5252/z2013n4a5

\begin{abstract}
The extreme south of Madagascar is noted for the endemism of its marine biota, notably molluscs. Six new species of Muricidae Rafinesque, 1815 are described in the present paper; three in the subfamily Muricinae Rafinesque, 1815: Chicoreus (Triplex) kantori n. sp., Naquetia manwaii n. sp. and Dermomurex (Dermomurex) charlesi n. sp.; two in the subfamily Muricopsinae Radwin \& D'Attilio, 1971: Favartia (Favartia) tantelyi n. sp. and Favartia (Pygmaepterys) fournierae n. sp.; and one in the subfamily Rapaninae Gray, 1853: Semiricinula bozzettii n. sp. Similar species from Madagascar and from other regions are compared and illustrated. The radula of Naquetia manwaii n. sp. and of Semiricinula bozzettii n. sp. are illustrated.
\end{abstract}

\section{RÉSUMÉ}

Description de nouvelles espèces de Muricidae (Mollusca: Gastropoda) récoltées durant l'Expédition ATIMO VATAE dans le "Grand Sud" malgache.

Le « Grand Sud » malgache est connu pour l'endémisme de sa faune marine, notamment les mollusques. Six nouvelles espèces de Muricidae Rafinesque, 1815 sont décrites dans le présent article ; trois dans la sous-famille des Muricinae Rafinesque, 1815 : Chicoreus (Triplex) kantori n. sp., Naquetia manwaii n. sp. et Dermomurex (Dermomurex) charlesi n. sp. ; deux dans la sous famille des Muricopsinae Radwin \& D'Attilio, 1971 : Favartia (Favartia) tantelyi n. sp. et Favartia (Pygmaepterys) fournierae n. sp. ; et une dans la sous famille des Rapaninae Gray, 1853 : Semiricinula bozzettii n. sp. Des espèces similaires de Madagascar et d'autres régions sont comparées et illustrées. Les radulas de Naquetia manwaii n. sp. et de Semiricinula bozzettii n. sp. sont illustrées. 


\section{INTRODUCTION}

Our knowledge of the marine biodiversity of Madagascar is to a very large extent based on research carried in the regions of Nossi-Bé and Tuléar (Toliara), both located in the "Western and Northern Madagascar" marine ecoregion (Spalding et al. 2007) and characterized by extensive coral reefs ecosystems. By contrast, the "Deep South" of Madagascar is an oceanic region of fierce promontories, open bays and extensive algal belts. The lack of infrastructures has arguably made it the least visited and least known coastline in the country. The marine hydroclimate is characterized by coastal upwelling with cold surface water and high concentrations of chlorophyll-a (Lutjeharms \& Machu 2000), with winter sea surface temperatures as low as $21.5^{\circ} \mathrm{C}$, vs $24-25^{\circ} \mathrm{C}$ or more elsewhere around Madagascar (Piton \& Laroche 1993). From the late 1990s, new species of molluscs started to be discovered on the coastline of the regions Anosy and Androy, first serendipitously as a by-product of the local lobster fishery (e.g., Bouchet 1999), and later specifically attracting shell collectors and amateur taxonomists (e.g., Bozzetti 2006, 2008). These scattered findings and the unique oceanographic background together suggested that the "Deep South" of Madagascar had a potential for more discoveries, which was what motivated a large-scale exploring expedition that sampled the benthos of the region in April-June 2010. The name of the expedition, ATIMO VATAE, means "Deep South" in the regional Antandroy language. For baseline information on the project, see http:// laplaneterevisitee.org/en/87/accueil.

The expedition collected over 90 species of Muricidae Rafinesque, 1815, many of which were tissueclipped for molecular sequencing. A thorough report on the Muricidae from Madagascar "Deep South" is being worked up in collaboration with Marco Oliverio (University of Rome La Sapienza). It will review the nominal species described or reported from the region, and discuss generic allocations based on molecular data. The present paper is a progress report restricted to the description of six new species from the shore and upper part of the continental shelf.

\section{MATERIAL AND METHODS}

\section{METHODS FOR MORPHOLOGICAL TAXONOMY}

The characters used here to describe the shell morphology are the general aspect of the shell, the shape and size, the colour, the shape of the spire and the number of protoconch and teleoconch whorls, the description of the protoconch, the shape of the teleoconch whorls and the description of the suture and of the subsutural band, of the axial and of the spiral sculpture, of the aperture and of the siphonal canal. When known the characters of the operculum and radula are also provided.

Unless otherwise mentioned, the species descriptions are based on all the examined specimens or on a representative suite.

All the material studied is deposited in the MNHN unless otherwise indicated. Acronyms of other repositories are available below.

\section{TAXONOMY OF MURICIDAE}

To date, we individually or together have used subgenera in most of our papers in accordance with well-established precedent. This was done in conformity with previous authors who recognized common relationships between genera and subgenera in Muricidae. The geological history also favoured the use of subgenera based on ancestral lineages from which other fossil or Recent groups seem to have derived (Vokes 1964, 1971a, 1971b and subsequent studies).

Nevertheless, in light of recent genetic studies (Barco et al. 2010, Claremont et al. 2011a, b, $2013 \mathrm{a}, \mathrm{b})$ and of the profound reorganization of the systematics of Muricidae, subgenera seem to be inappropriate and are now used rarely, except in some cases (Claremont et al. 2013b).

Accordingly, it might seem preferable to avoid the use of subgenera altogether in most cases, to conform with the recent studies. However, many supraspecific taxa in the numerous muricid subfamilies have not yet been genetically analysed, including some subgenera used in this paper. We will, of course, adopt the new classification, but for those that are still under study, we will continue to use the classification as previously established while awaiting further genetic results. 

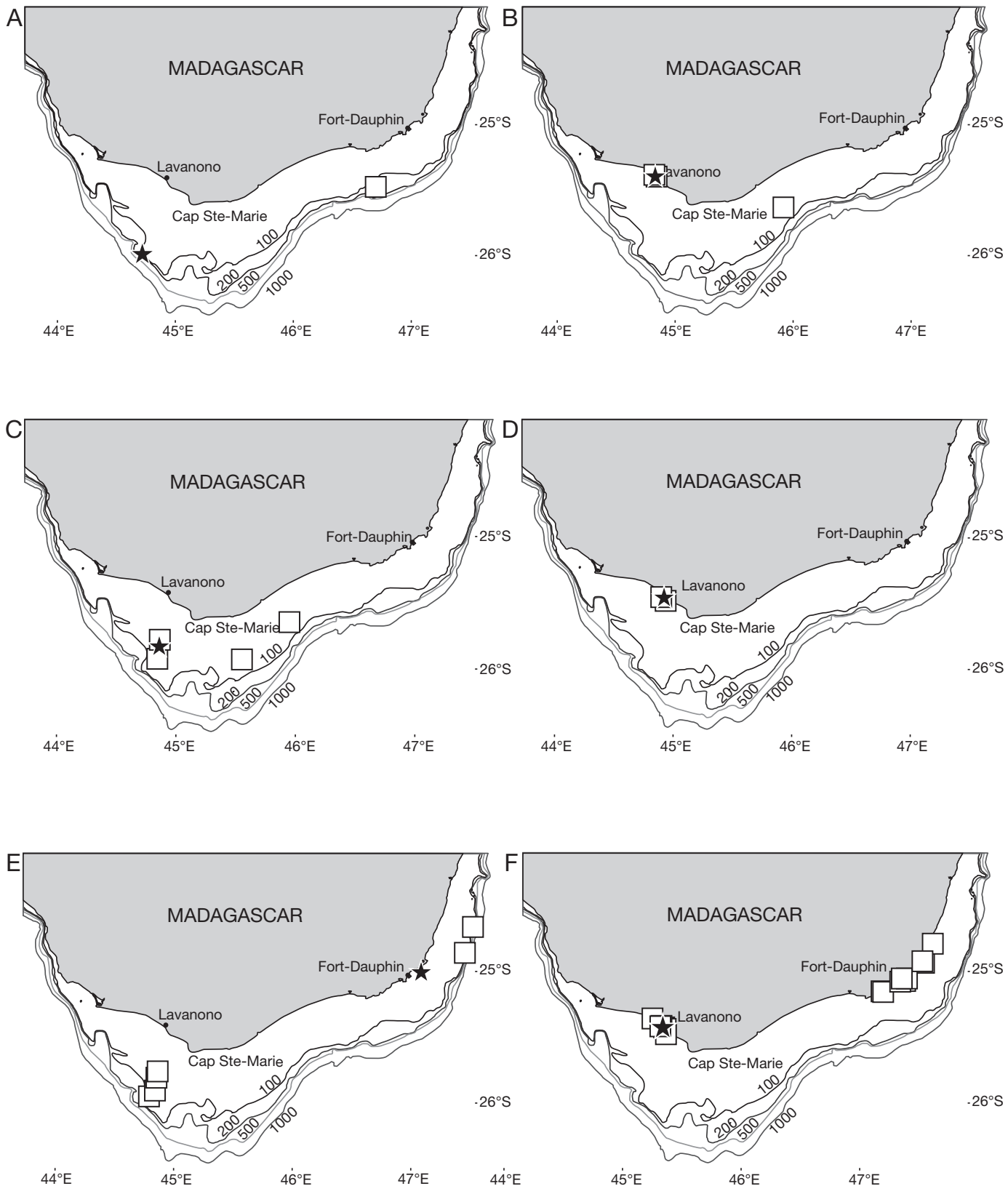

$\underline{50 \mathrm{~km}}$

FIG. 1. - Distribution of the six new species described herein: A, Chicoreus (Triplex) kantori n. sp.; B, Naquetia manwaii n. sp.; C, Dermomurex (Dermomurex) charlesi n. sp.; D, Favartia (Favartia) tantelyi n. sp.; E, Favartia (Pygmaepterys) fournierae n. sp.; F, Semiricinula bozzettii n. sp. Symbols: $\star$, type locality; $\square$, other occurences. 

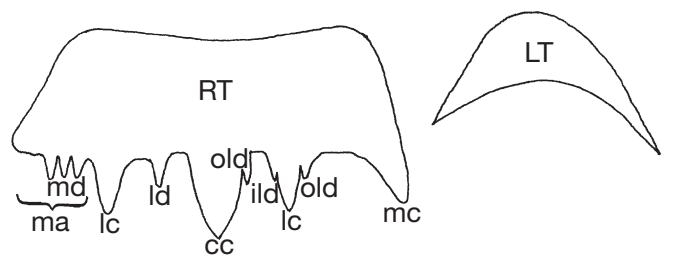

FIG. 2. - Schematic drawing of a muricid radula (after Kool 1993). The morphology of the radula is described starting from the rachidian tooth followed by the lateral teeth. Abbreviations: see Material and methods.

\section{ABBREVIATIONS}

Repositories

AMS The Australian Museum, Sydney;

Coll. RH Collection Roland Houart;

MNHN Muséum national d'Histoire naturelle, Paris;

NM Natal Museum, Pietermaritzburg;

RMNH Nederlands Centrum voor Biodiversiteit (formerly Nationaal Natuurhistorisch Museum), Leiden;

WAM Western Australian Museum, Perth.

\section{Field work}

$\mathrm{CP} \quad$ chalut à perche (Beam trawl);

DW drague Warén (Warén dredge).

\section{Specimens}

ad adult;

BOLD Barcode Of Life Datasystem (www.boldsystems.org);

dd empty shell(s);

juv

$\mathrm{lv}$ juvenile; live collected specimen(s)

Terminology used to describe the spiral cords and the apertural denticles (after Merle 1999 and 2001) Terminology in parentheses: erratic feature (Figs 3A-E, 6N)

$\mathrm{ab}$ abapical (or abapertural);

abis abapical infrasutural secondary cord (on subsutural ramp);

ABP abapertural primary cord on the siphonal canal;

abs abapertural secondary cord on the siphonal canal;

ad adapical (or adapertural);

adis adapical infrasutural secondary cord (on subsutural ramp);

ADP adapertural primary cord on the siphonal canal; ads adapertural secondary cord on the siphonal canal;

IP infrasutural primary cord (primary cord on subsutural ramp);

MP median primary cord on the siphonal canal;
$\mathrm{ms}$

P primary cord;

P1 shoulder cord:

P2-P6 primary cords of the convex part of the teleoconch whorl;

s secondary cord;

s1-s6 secondary cords of the convex part of the teleoconch whorl (example: $s 1=$ secondary cord between $\mathrm{P} 1$ and $\mathrm{P} 2$; $\mathrm{s} 2$ = secondary cord between $\mathrm{P} 2$ and $\mathrm{P} 3$, etc.);

SP subsutural cord;

t tertiary cord.

\section{Aperture}

D1 to D6 abapical denticles;

ID Infrasutural denticle.

Morphology of the radula (Fig. 2)

cc central cusp;

ild inner lateral denticle;

lc lateral cusp;

ld lateral denticle;

LT lateral tooth;

ma marginal area;

mc marginal cusp;

md marginal denticles;

old outer lateral denticle;

RT rachidian tooth.

\section{SYSTEMATICS}

Family MURICIDAE Rafinesque, 1815

Subfamily MuricinaE Rafinesque, 1815

Genus Chicoreus Montfort, 1810

Subgenus Triplex Perry, 1810

TYPE SPECIES. - Triplex foliatus Perry, 1810 (Suppressed - ICZN opinion 911 - in favour of Murex palmarosae Lamarck, 1822), Indo-West Pacific (by monotypy).

Chicoreus (Triplex) kantori $\mathrm{n} . \mathrm{sp}$.

(Figs 1A; 3A; 4A-C; 7F)

Type Material. - Holotype (lv), MNHN 26504 and 1 paratype MNHN 26505. 

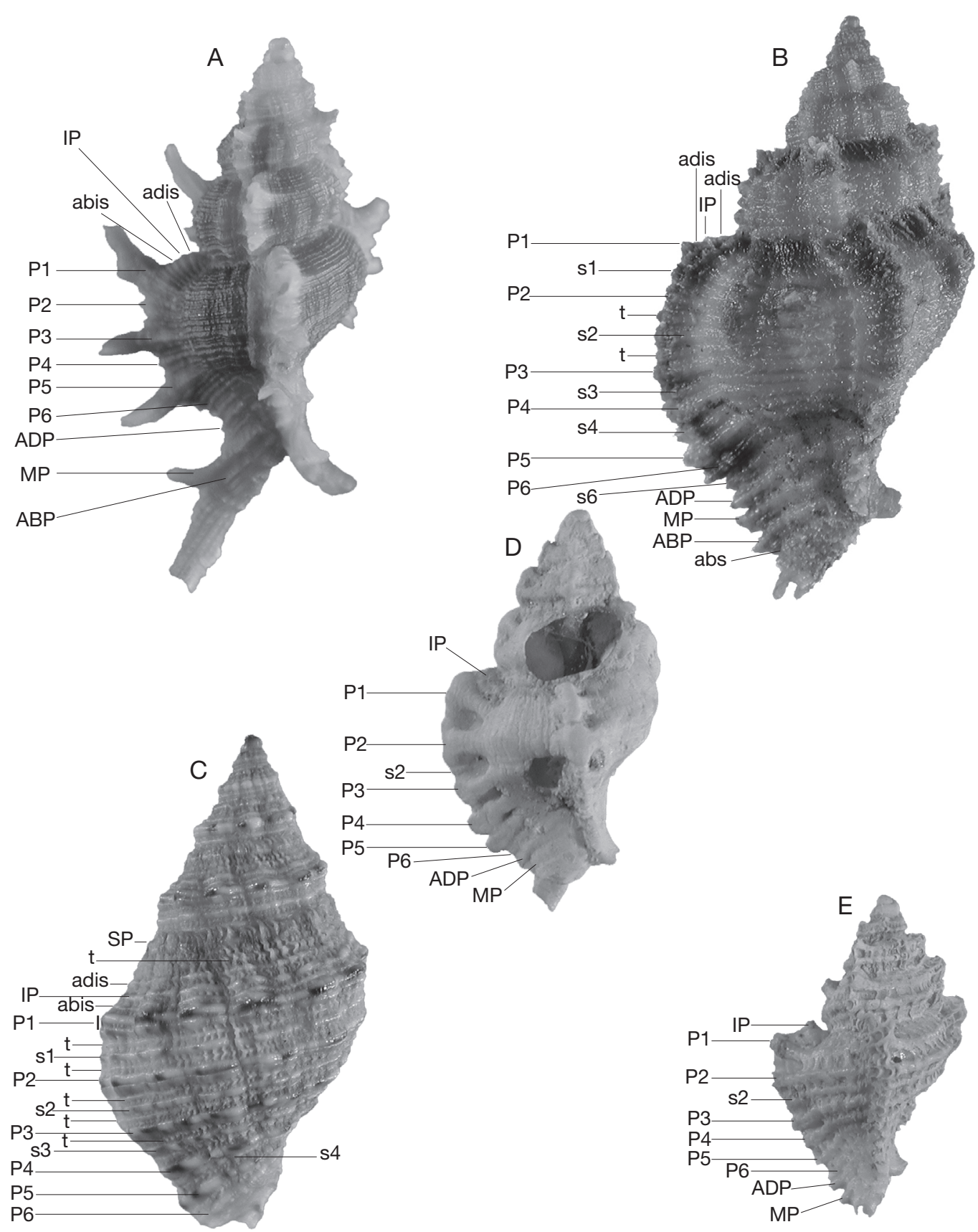

FIG. 3. - Spiral cords morphology: A, Chicoreus (Triplex) kantori n. sp. (holotype), 19.1 mm; B, Naquetia manwaii n. sp. (holotype), $34 \mathrm{~mm}$; C, Semiricinula bozzettii n. sp. (holotype), 16 mm; D, E, Favartia (Pygmaepterys) fournierae n. sp.; D, Holotype, 10.2 mm; E, Paratype MNHN 26519, $8.4 \mathrm{~mm}$. Abbreviations: see Material and methods. 
TYPE LOCALITY. - SW Cap Sainte Marie, 2559.0'S, 44ㄴ⒊3'E, 97-98 m [ATIMO VATAE: stn DW3601].

Material EXAMINED. - ATIMO VATAE: stn CP3545,

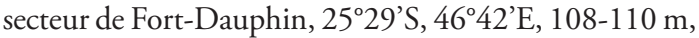
1 dd (paratype MNHN 26505). - Stn DW3601, SW

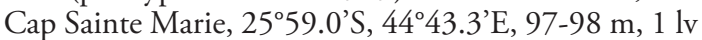
(holotype MNHN 26504).

Distribution. - South Madagascar, live in 97-98 m, shells in 108-110 m.

ETYMology. - This species is named after Yuri Kantor, a longtime and always cheerful and attentive friend, specialist in systematics and anatomy of neogastropods. Yuri has participated in many expeditions organized by MNHN, including ATIMO VATAE in Fort-Dauphin and on board the trawler Nosy Bé 11 .

\section{DESCRIPTION}

Shell small for the subgenus, up to $19.1 \mathrm{~mm}$ in height at maturity (holotype). Height/width ratio 1.92 (holotype), broadly ovate, spinose, lightly built. Shoulder ramp weakly sloping, weakly convex.

Protoconch and 2 first adapical teleoconch whorls light tan, becoming darker from third whorl, fourth and fifth whorls reddish brown with slightly paler variceal spines. Aperture brown, edge white and pale brown.

Spire high with 1.45 protoconch whorls and teleoconch up to 5.2 broadly convex, weakly shouldered, spinose and nodose whorls. Suture impressed. Protoconch large, broad, whorls rounded but weakly flattened, last whorl minutely punctuate, width $1100 \mu \mathrm{m}$, height $900 \mu \mathrm{m}$. Terminal lip broad, rounded, weakly erect, almost straight.

Axial sculpture of teleoconch whorls consisting of low, narrow, nodose ribs and narrow, high, rounded, spinose varices. First whorl with eight or nine ribs, second to fourth whorl with three varices and three nodose ribs, last whorl with three varices and three to five irregularly shaped, low or very low, intervariceal ribs. Spiral sculpture of low, nodose, primary, secondary and tertiary cords and narrow lirae, almost indistinguishable between penultimate and last (apertural) varix. First whorl with P1-P3 or P1-P4, second with P1, s1, P2, P3, P4, beginning of IP, third with IP, adis, P1, s1, P2, s2, P3, P4, fourth with adis, IP, abis, P1, s1, P2, s2, P3, s3, P4 and several additional narrow threads, last whorl with adis, IP, abis, P1, s1, P2, s2, P3, s3, P4, s4, P5, s5, P6, s6, ADP, ads, MP, ms, ABP, abs and additional threads on shoulder ramp, convex part of last whorl and siphonal canal. P1, P3, P5 and MP giving rise to moderately long, narrow, weakly frondose, narrowly open spines on axial varices, P2, P4 and P6 narrow with very short, broadly open spinelets.

Aperture moderately small, ovate. Columellar lip narrow, flaring, smooth, rim partially erect, adherent on small portion at adapical extremity. Anal notch shallow, broad. Outer lip erect, smooth with five weak, low, elongate denticles within: ID, D1-D5. Siphonal canal long, narrow, strongly abaxially bent, narrowly open with a single short spine extending from MP.

Operculum and animal not examined.

\section{REMARKS}

Chicoreus (Triplex) kantori n. sp. can be separated immediately from all other Triplex species by having three narrow, very weakly frondose spines, extending from P1, P3 and P5 on the axial varices, by the small weakly adapically curved spine extending from MP and by the strongly abaxially bent siphonal canal.

Chicoreus (T.) crosnieri Houart, 1985 (Fig. 4D-E) is comparatively larger with broader and higher intervariceal axial nodes, more strongly frondose and more numerous variceal spines, usually extending from P1, P3, P5 and P6, P2 and P4 being very narrow and only in very few specimens extending as very short, narrow variceal spines, otherwise spineless. The siphonal canal is straighter and bears a relatively long spine, extending from MP and a shorter one from ABP, both strongly bent abapically.

Chicoreus (T.) zululandensis Houart, 1989 (Fig. 4F) differs in having a relatively larger and more rounded protoconch and also in having more numerous variceal spines and a straighter siphonal canal with weakly curved, abapically bent spines: ADP, MP, ABP.

Chicoreus (T.) boucheti Houart, 1983, C. (T.) paucifrondosus Houart, 1988 and C. (T.) subpalmatus Houart, 1988 from New Caledonia also have a strongly abaxially bent siphonal canal as observed in C. (T.) kantori $\mathrm{n}$. sp. rather than the straight canal of other Triplex species, but they differ by many other shell characters and do not need to be compared further here. 


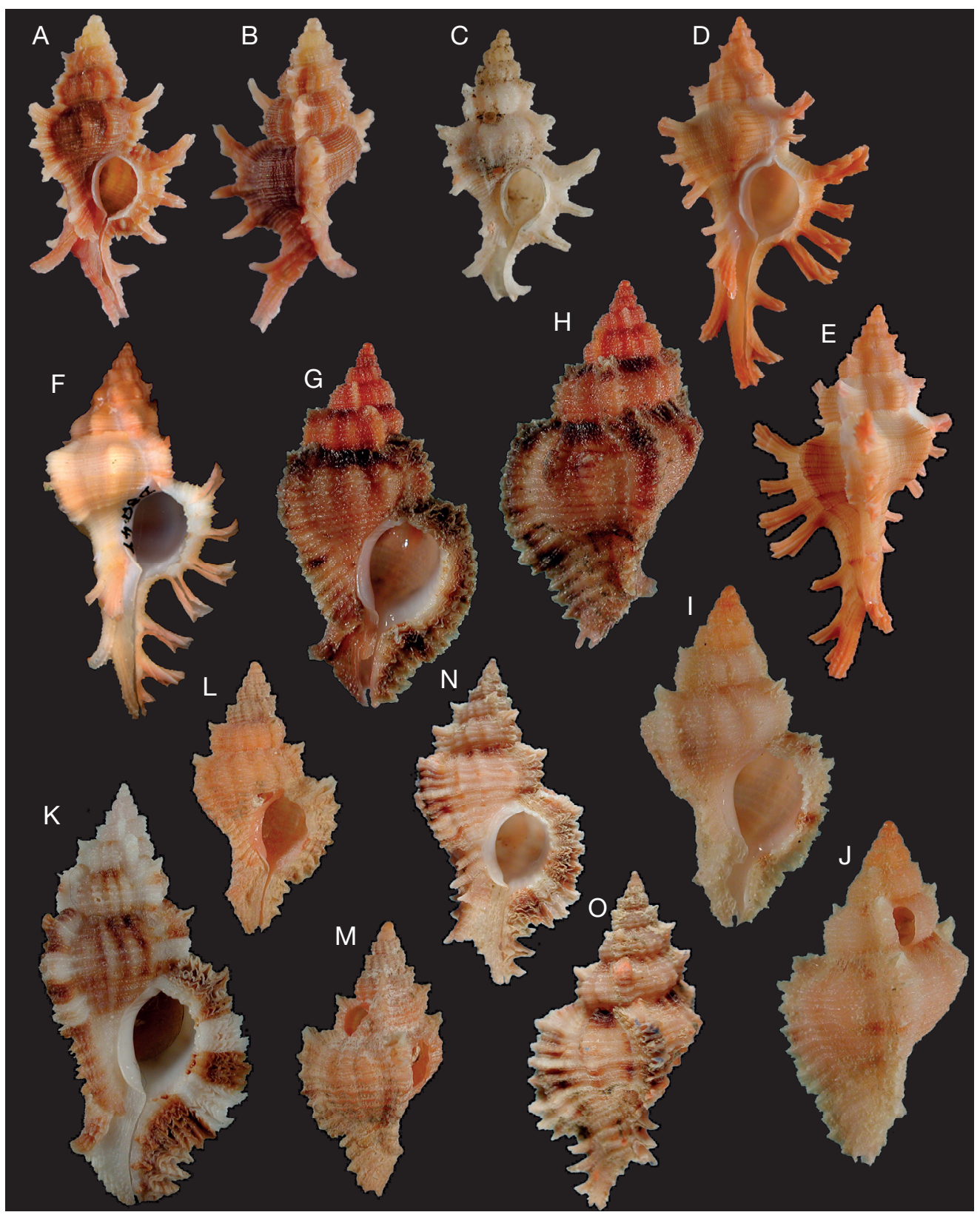

FIG. 4. - A-C, Chicoreus (Triplex) kantori n. sp.; A, B, holotype MNHN 26504, 19.1 mm; C, paratype MNHN 26505, 17.6 mm; D, E, Chicoreus (Triplex) crosnieri Houart, 1985, ATIMO VATAE: stn CP3521, MNHN, 40.3 mm; F, Chicoreus (Triplex) zululandensis Houart, 1989, holotype NM D8049, 31 mm (photo courtesy A. Marais); G-J, Naquetia manwaii n. sp.; G, H, holotype MNHN 26506, $34 \mathrm{~mm}$; I, J, paratype, MNHN 26510, 23 mm; K-M, Naquetia vokesae (Houart, 1986); K, Zanzibar, West of Stone Own, 38.9 mm, RH; L, M, ATIMO VATAE: stn TB08, 14.8 mm (juvenile), MNHN; N, O, Chicomurex turschi (Houart, 1981), Papua New Guinea, Hansa Bay, off Durangit, 45-60 m, $36 \mathrm{~mm}$, paratype $\mathrm{RH}$. 


\section{Genus Naquetia Jousseaume, 1880}

TYPE SPECIES. - Murex triqueter Born, 1778, Indo-West Pacific (by original designation).

\section{REMARKS}

Naquetia and Chicomurex Arakawa, 1964 are two muricine genera with closely similar shell morphology, with an average height of 40-120 mm in Naquetia and 30-85 mm in Chicomurex. The protoconch is paucispiral, consisting of 1.52 whorls, or conical of sinusigera type, with 3-3.5 glossy whorls, usually with a narrow keel abapically. Each teleoconch whorl bears three rounded, squamous varices from the second or third whorl, with short, broadly open spines connected by squamous webbing. The radula is similar in the two genera, consisting of crowded rows of teeth with a rachidian bearing a large, broad, triangular central cusp (Houart 1992: figs 116-128) and Figure 8A, B.

The type species of Chicomurex, $C$. laciniatus (Sowerby, 1841) differs from the type species of Naquetia in having a broader and more globose shell, a comparatively lower spire and a proportionally larger and broader aperture. Within these two genera, all species consistently exhibit this distinction. The two genera are also distinct in a molecular phylogenetic analysis (Barco et al. 2010).

The new species described here is included in $\mathrm{Na}$ quetia in spite of the slightly broader shell relative to its length compared to other Naquetia species and the relatively low spire. However, it differs from Chicomurex in having a short, broad, squamous siphonal canal, relatively shorter variceal spines and a more strongly triangular outline, which are typical characters of Naquetia.

\section{Naquetia manwaii n. sp.}

(Figs 1B; 3B; 4G-J; 7G; 8A, B)

Type Material. - Holotype (lv), MNHN 26506 and 4 paratypes MNHN 26507-26510; 1 paratype RH.

TYPE LOCALITY. - South Madagascar, West of Lavanono,

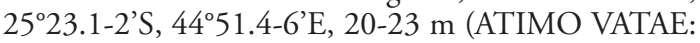
stn BP21).
MATERial EXAmined. - ATIMO VATAE: stn BP21,

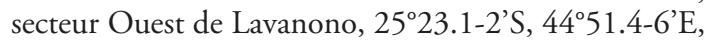
20-23 m, $1 \mathrm{lv}$ (holotype MNHN 26506 sequenced as IM-2009-14457 BOLD ID BOMGA007-13, GenBank accession number for COI gene KC860503). - Stn BP22,

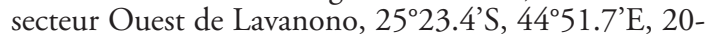
$22 \mathrm{~m}, 1 \mathrm{lv}$ (paratype MNHN 26507 sequenced as IM-2009-14456 BOLD ID BOMGA005-13, GenBank accession number for COI gene KC860505), 2 dd (1 paratype MNHN 26508, 1 paratype RH). - Stn BP42, secteur Ouest de Lavanono, $25^{\circ} 22.8-23.7^{\prime} \mathrm{S}, 4^{\circ} 51.1^{\prime} \mathrm{E}, 18-21 \mathrm{~m}$, $1 \mathrm{lv}$ (paratype MNHN 26509. sequenced as IM-200914729 BOLD ID BOMGA006-13, GenBank accession number for COI gene KC860504). - Stn CP3624,

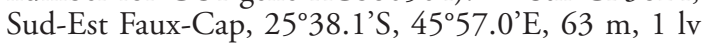
(paratype MNHN 26510 sequenced as IM-2009-14504 BOLD ID BOMGA004-13, GenBank accession number for COI gene KC860506).

Distribution. - South Madagascar, live in 20-21 m, shells in $20 \mathrm{~m}$.

ETymology. - At the request of Philippe Bouchet, this species is named after Man Wai Rabenevanana, longtime director of Institut d'Halieutique et des Sciences Marines (IH.SM) of Université de Toliara (Tuléar), known as "Man Wai" to his friends and colleagues. Man Wai greatly facilitated the expedition by supporting applications for permits and delegating students and staff to the field sites.

\section{DESCRIPTION}

Shell medium sized for the genus, up to $34 \mathrm{~mm}$ in height at maturity (holotype). Height/width ratio 1.9-2.0. Broadly biconical, weakly spinose, lightly built, squamous. Subsutural ramp narrow, weakly sloping, concave or straight.

Greyish-brown. Protoconch and two or three first teleoconch whorls pink or pinkish-brown. Subsutural ramp with a narrow dark brown band below suture, varices of last teleoconch whorl with dark brown blotches, extending on the siphonal canal. Occasionally dark brown, narrow, incomplete spiral bands on last whorl. Aperture white or bluish-white.

Spire high with 1.15-1.5 protoconch whorls and teleoconch up to six broad, strongly convex, shouldered, squamous and nodose whorls. Suture adpressed. Protoconch large, broad, whorls rounded, smooth, maximum width $1150 \mu \mathrm{m}$, height 1100-1200 $\mu \mathrm{m}$. Terminal lip delicate, broad, erect, weakly curved.

Axial sculpture of teleoconch whorls consisting of moderately high, broad, rounded ribs and high, 
narrow, rounded, squamous varices. Other axial sculpture of low growth lamellae, more apparent on spiral cords, giving a squamous appearance to surface. First whorl with 14 or 15 ribs, second with 14 or 15 , beginning of varices, third and fourth whorl with three varices and four or five intervariceal ribs, fifth whorl with three varices and three intervariceal ribs, last whorl with three varices and three intervariceal elongate knobs or two knobs with a third reduced one. Apertural varix broadest, ventrally strongly squamous.

Spiral sculpture of low, rounded, primary, secondary and tertiary cords. First teleoconch whorl with narrow $\mathrm{P} 1-\mathrm{P} 4$, second whorl with $\mathrm{P} 1-\mathrm{P} 4$, start of IP and s1, third with IP, P1, s1, P2, s2, P3, s3, P4; P4 occasionally covered by next whorl, fourth whorl with adis, IP, P1, s1, P2, s2, P3, s3, P4, fifth and last whorls with adis, IP, abis, P1, s1, P2, t, s2, t, P3, s3, P4, s4, P5, P6, s6, (t), ADP, MP, ABP, (abs); s1 larger than P1 on penultimate and last whorls. P4-P6 broadest cords. Primary and secondary cords giving rise to very short, broadly open spines. P1 spine slightly longer. All spines connected by frilly webbing.

Aperture large, broad, broadly ovate. Columellar lip narrow with weak knob abapically, two or three weak folds and low but obvious parietal tooth at adapical extremity. Lip weakly erect abapically, otherwise adherent. Anal notch moderately deep, narrow. Outer lip weakly erect, denticulate, with weak, low, narrow lirae or elongate denticles within: ID split, D1-D4 split, D5, D6. Presence of secondary split lirae between D1 and D2. Siphonal canal short, broad, strongly dorsally bent at tip, narrowly open, with three frondose, webbed, short spines at ADP, MP and ABP.

Operculum light brown, ovate with apical nucleus.

Radula (Fig. 8A, B) with crowded rows of teeth with a broad, long, triangular, acute central cusp, short, narrowly triangular lateral denticles and broad, long, triangular, lateral cusps. Lateral tooth sickle shaped, broad.

\section{REMARKS}

Three species of Naquetia are recorded from Madagascar or nearby areas: $N$. barclayi (Reeve, 1845),
N. cumingii (A. Adams, 1853) and N. vokesae (Houart, 1986).

Naquetia barclayi is very different and does not need to be compared here.

Naquetia cumingii is less squamous, reaching a larger size relative to the number of teleoconch whorls and chiefly differs in having a very different, smaller protoconch, consisting of 2-2.15 whorls with a strongly keeled first whorl.

Naquetia vokesae (Fig. 4K-M) differs in having a relatively narrower shell with a higher spire (height/ width ratio 2.1-2.3 vs 1.9-2.0 in N. manwaii n. sp.), a protoconch only a third of the size, the penultimate and last teleoconch whorls with three or four narrow intervariceal, axial ridges vs two or rarely three elongate, broad knobs in N. manwaii n. sp., and in having a narrower aperture.

Due to the similar-looking shells, two species of Chicomurex are here also compared: C. turschi (Houart, 1981) and C. rosadoi Houart, 1999, from Zululand (South Africa) and Mozambique, respectively. The record of $C$. turschi from Madagascar in Houart (1992: 123, fig. 433) has not been confirmed by additional material. The specimens illustrated by Merle et al. (2011: pl. 78, figs 13a, b, 14) as $C$. turschi from southern Madagascar are most probably specimens of $N$. vokesae.

Chicomurex turschi (Fig. 4N, O) differs from $N$. manwaii n. sp. in having a taller, more slender spire with narrower teleoconch whorls, a comparatively smaller aperture, a more slender, longer siphonal canal and a smaller protoconch, less than half the size of $N$. manwaii n. sp.

Chicomurex rosadoi, described from southern Mozambique, has a broader, more globose protoconch, probably denoting intracapsular larval development, broader spire whorls, a broader, globose last whorl, and a narrower siphonal canal.

\section{Genus Dermomurex Monterosato, 1890}

$$
\text { Subgenus Dermomurex Monterosato, } 1890
$$

TYPE SPECIES. - Murex scalarinus Bivona-Bernardi, 1832 (junior synonym of Murex scalaroides Blainville, 1829), Mediterranean (by original designation). 


\section{REMARKS}

The genus Dermomurex is not widely present in the Indo-West Pacific. Only two species have been recorded from the western Indian Ocean, both from South Africa, in the vicinity of Zululand: Dermomurex (Takia) africana Vokes, 1978 and D. (T.) infrons Vokes, 1974.

Dermomurex was included by Keen (1971) in the subfamily Aspellinae Keen, 1971, along with the type genus Aspella Mörch, 1877. Based on radular features, Dermomurex and Aspella are similar to muricines in having a flat pentacuspidate rachidian tooth.

The results obtained by Barco et al. (2010) give high support to a clade composed of Dermomurex, Attiliosa Emerson, 1968 and the Muricopsinae Radwin \& D'Attilio, 1971, but the most appropriate subfamilial classification remains uncertain, because they are not retrieved as a monophyletic group. Aspella was missing in the dataset, but close similarity with Dermomurex is an undeniable fact, and it is possible that its inclusion in future work might support the recognition of the subfamily Aspellinae.

\section{Dermomurex (Dermomurex) charlesi n. sp.} (Figs 1C; 5A-C; 7H)

TYPe MATERIAL. - Holotype MNHN 26511 and 5 paratypes MNHN 26512-26514, 1 RH.

TYPe locality. - South Madagascar, SW Cap Sainte Marie, $25^{\circ} 48.4^{\prime} \mathrm{S}, 44^{\circ} 51.1^{\prime} \mathrm{E}, 44-46 \mathrm{~m}$ (ATIMO VATAE: stn DW3606).

MATERIAL EXAMINED. - ATIMO VATAE: stn CP3579, Sud de Faux-Cap, 255 54.5'S, 45³3.2'E, 65-66 m, 1 dd (paratype MNHN 26512). - Stn DW3605, SW Cap Sainte Marie, $24^{\circ} 54.5^{\prime} \mathrm{S}, 44^{\circ} 51.0^{\prime} \mathrm{E}, 56-57 \mathrm{~m}, 1 \mathrm{dd}$, juv (paratype MNHN 26513). - Stn DW3606, SW Cap Sainte Marie, $25^{\circ} 48.4^{\prime}$ S, $44^{\circ} 51.1^{\prime} \mathrm{E}, 44-46 \mathrm{~m}, 1 \mathrm{dd}$ (holotype MNHN 26511). - Stn DW3607, SW Cap Sainte Marie, $25^{\circ} 45.7^{\prime} \mathrm{S}, 44^{\circ} 52.0^{\prime} \mathrm{E}, 40-41 \mathrm{~m}, 1 \mathrm{dd}$ (paratype RH). - Stn CP3624, Sud-Est Faux-Cap, 25 38.1'S, $45^{\circ} 57.0^{\prime} \mathrm{E}, 63 \mathrm{~m}, 3 \mathrm{dd}$ (paratypes MNHN 26514).

DistribUtion. - South Madagascar, shells in 41-65 m.

ETYMology. - This species is named after Laurent Charles, curator at the Muséum d'Histoire Naturelle in Bordeaux. Laurent was a member of the ATIMO VATAE expedition field party and of several subsequent MNHN expeditions, combing skills as a collector, sorter and photographer of living micromolluscs.

\section{DESCRIPTION}

Shell medium-sized for the subgenus, up to $11.6 \mathrm{~mm}$ in height at maturity (holotype). Height/width ratio 2.0-2.1. Biconical, narrowly-ovate, weakly nodose, lightly built. Subsutural ramp narrow, weakly sloping, convex. Shell entirely covered by thick, dirty-white intritacalx with faint, shallow spiral striae, otherwise smooth, with deep pits along axial varices. Shell entirely white. Aperture light peach within.

Spire high with 1.5 protoconch whorls and teleoconch up to 5+ weakly convex, weakly shouldered, nodose whorls. Suture strongly impressed. Protoconch small, whorls rounded, smooth; maximum width 700-800 $\mu \mathrm{m}$, height $700 \mu \mathrm{m}$. Terminal lip narrow, erect, weakly rounded, oblique.

Axial sculpture of teleoconch whorls consisting of narrow varices decreasing in height and becoming broader adapically. First teleoconch whorl with six varices that overlap onto the protoconch. Second to penultimate whorl with six varices. Last whorl with four or five low, broad varices. Spiral sculpture weak, flat, broad. Primary cords indistinguishable on adapical teleoconch whorls. Last whorl with low, broad, weakly nodose P1-P6.

Aperture moderately small, ovate. Columellar lip narrow, smooth, rim adherent, weakly detached abapically. Anal notch indiscernible. Outer lip smooth, smooth within or with very weak, broad, low denticles: D1-D6, of which only (D2-D3), D4, D5 and D6 are visible in the holotype. Siphonal canal short, broad, weakly dorsally recurved, open.

Operculum and radula not examined.

\section{REMARKS}

Dermomurex (Dermomurex) charlesi n. sp. is here compared with three Australian species: $D$. (D.) agnesae Vokes, 1995 from Western Australia, D. (D.) angustus (Verco, 1895) from South Australia and D. (D.) goldsteini (Tenison-Woods, 1876) from New South Wales and Tasmania. 


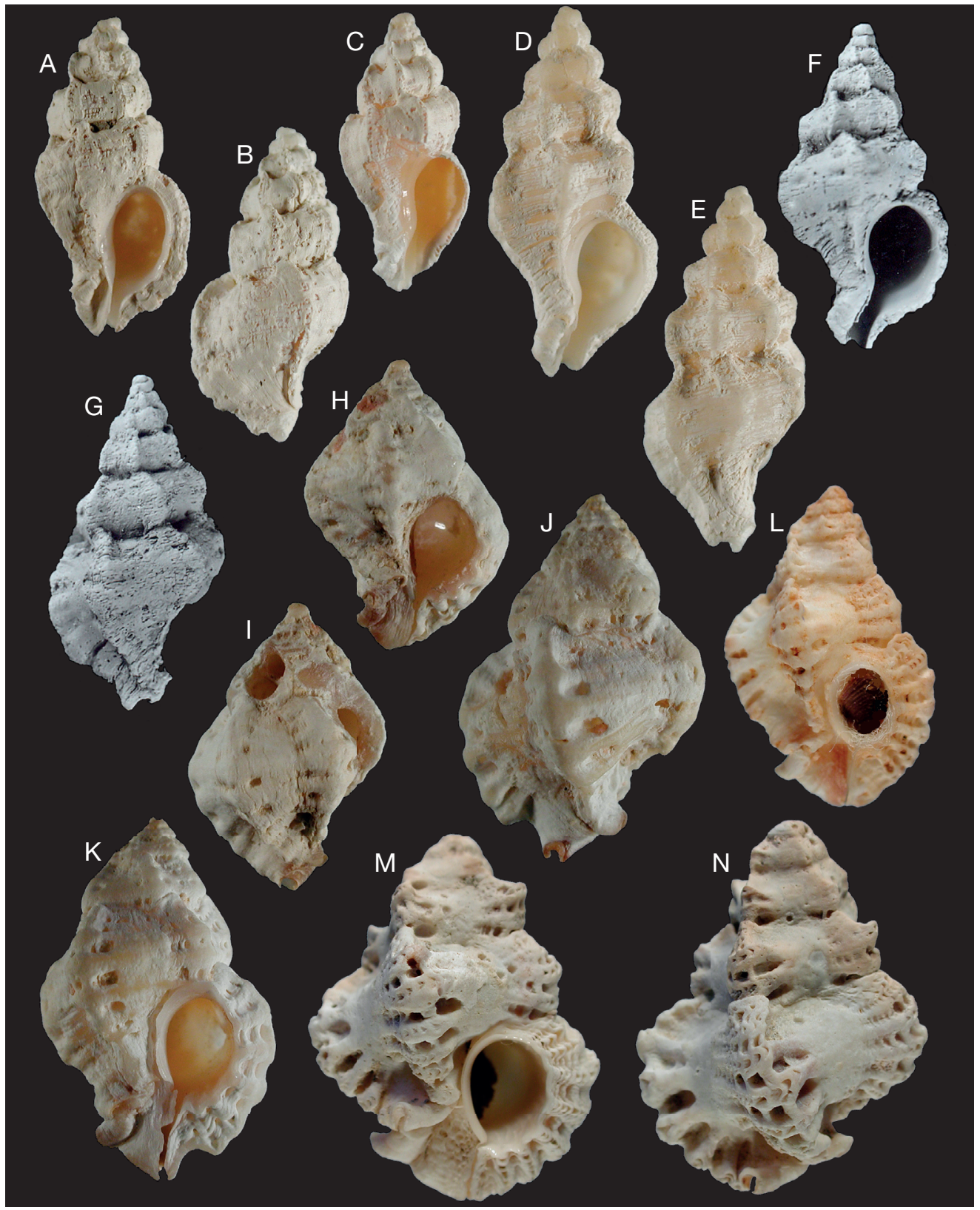

FIG. 5. - A-C, Dermomurex (D.) charlesi n. sp.; A, B, holotype MNHN 26511, 11.6 mm; C, paratype MNHN 2651, 8.2 mm; D, E, Dermomurex (D.) goldsteini (Tenison-Woods, 1876), Gerringong, S. NSW, Australia, $15.8 \mathrm{~mm}, \mathrm{RH}$; F, G, Dermomurex (D.) agnesae Vokes, 1995, holotype WAM 209-94, 13.9 mm (photo courtesy E. H. Vokes; scan of a white and black photograph); H-K, Favartia (F.) tantelyi n. sp.; H, I, holotype MNHN 26515, 8.1 mm; J, K, paratype MNHN 26516, 15.7 mm; L, Favartia (F.) eastorum Houart, 1998, Peak Id, N. of Exmouth Gulf, W. Australia, $18.7 \mathrm{~mm}$, paratype RH; M, N, Favartia (F.) brevicula (Sowerby, 1864), Mauritius, $30.8 \mathrm{~mm}$, coll. RH. 
Dermomurex (D.) agnesae (Fig. 5F, G) differs in having a comparatively larger and broader shell with a height/width ratio of 1.9 vs 2.0-2.1 in $D$. (D.) charlesi n. sp., and in having a conical, acute spire with only five axial varices from the second to the last teleoconch whorls (Vokes 1985) and a somewhat larger aperture.

Dermomurex (D.) angustus differs in having a more slender and elongate shell (height/width ratio 2.22.4) with distinctive, rounded, broad axial varices.

Dermomurex (D.) goldsteini (Fig. 5D, E) is a comparatively somewhat larger shell, reaching $21 \mathrm{~mm}$ in height, with a comparatively smaller aperture, slightly more strongly shouldered teleoconch whorls and more conspicuous, higher spiral cords.

Subfamily MURICOPSINAE

Radwin \& D'Attilio, 1971

Genus Favartia Jousseaume, 1880

Subgenus Favartia Jousseaume, 1880

TYPE SPECIES. - Murex breviculus Sowerby, 1834, IndoWest Pacific (by original designation).

\section{Favartia (Favartia) tantelyi n. sp.} (Figs 1D; 5H-K)

Type Material. - Holotype MNHN 26515 and 2 paratypes MNHN 26516 and 26517.

TYPE LOCALITY. - South Madagascar, sector of Lavanono, $25^{\circ} 26.8^{\prime}$ S, 44⒌ 54.9'E, 27 m (ATIMO VATAE: stn BS03).

Material EXAMINED. - ATIMO VATAE: stn BS03, secteur de Lavanono, $25^{\circ} 26.4^{\prime} \mathrm{S}, 4^{\circ} 56.1^{\prime} \mathrm{E}, 14-18 \mathrm{~m}$, $1 \mathrm{lv}$, juv (holotype MNHN 26515 sequenced as IM2009-22474 BOLD ID BOMGA002-13, GenBank accession number for COI gene KC860502). - Stn BV08, secteur de Lavanono, $25^{\circ} 26.8^{\prime} \mathrm{S}, 44^{\circ} 54.9^{\prime} \mathrm{E}, 27 \mathrm{~m}, 1 \mathrm{dd}$ (paratype MNHN 26516). - Stn BS12, Rocher de l'Albatros, $25^{\circ} 28.6^{\prime}$ 'S, $44^{\circ} 56.8^{\prime} \mathrm{E}, 12 \mathrm{~m}, 1 \mathrm{dd}$ (paratype MNHN 26517).

Distribution. - South Madagascar, shells in 12-27 m.

ETymology.- This species is named after Tantely Tianarisoa, of the Madagascar bureau of the Wildlife Conservation Society in Tananarive. Tantely was a member of the ATIMO VATAE expedition, taking part in the field work and databasing the coordinates and characteristics of the sampling stations.

\section{DESCRIPTION}

Shell small for the subgenus, up to $15.7 \mathrm{~mm}$ in height (paratype MNHN). Height/width ratio 1.5-1.6, biconical, broadly ovate, heavy, nodose. Subsutural ramp broad, strongly sloping, weakly concave. Shell entirely white. Aperture light peach.

Spire high with five broad, weakly shouldered, nodose whorls. Suture adpressed. Protoconch of 1.45 rounded whorls; width $700 \mu \mathrm{m}$, height $600 \mu \mathrm{m}$. Axial sculpture of teleoconch whorls consisting of strong, broad, rounded, nodose, moderately high varices. First whorl with eroded varices. Second whorl to penultimate whorl with six varices, last whorl with four or five varices connected preceding whorl. Varices weakly squamous abaperturally, adaperturally with narrow, deep pits between each pair of cords. Spiral sculpture of high, strong, broad primary cords, more apparent on axial varices. First whorl with broad P1 and P2, second and third whorl with narrow IP and broad P1 and P2, penultimate whorl with narrow IP, broad P1 and P2, P3 broadly covered by following whorl and by its axial varices. Last whorl with narrow IP, P1-P5 and narrow, almost obsolete P6 and ADP. P1 narrow, $\mathrm{P} 2$ and $\mathrm{P} 3$ broadest, P4 and P5 weakly narrower.

Aperture moderately large, ovate. Columellar lip narrow, smooth, rim partially erect, adherent at adapical extremity. Anal notch shallow, broad. Outer lip weakly erect, with six weak, elongate, narrow lirae within corresponding to D1-D6, D4D6 most obvious. Siphonal canal short, narrow, strongly dorsally recurved at tip, narrowly open.

Operculum and radula unknown.

\section{REMARKS}

Favartia (Favartia) tantelyi n. sp is clearly part of a group of species with solid, heavy shells including F. (F) brevicula (Sowerby, 1834), F. (F) minatauros Radwin \& D'Attilio, 1976, F. (F) tetragona (Broderip, 1833), F. (F.) eastorum Houart, 1998 and $F(F)$ confusa (Brazier, 1877). From these, two species have three varices on the last teleoconch whorl: $F$. (F) minatauros and $F(F)$ tetragona. They 


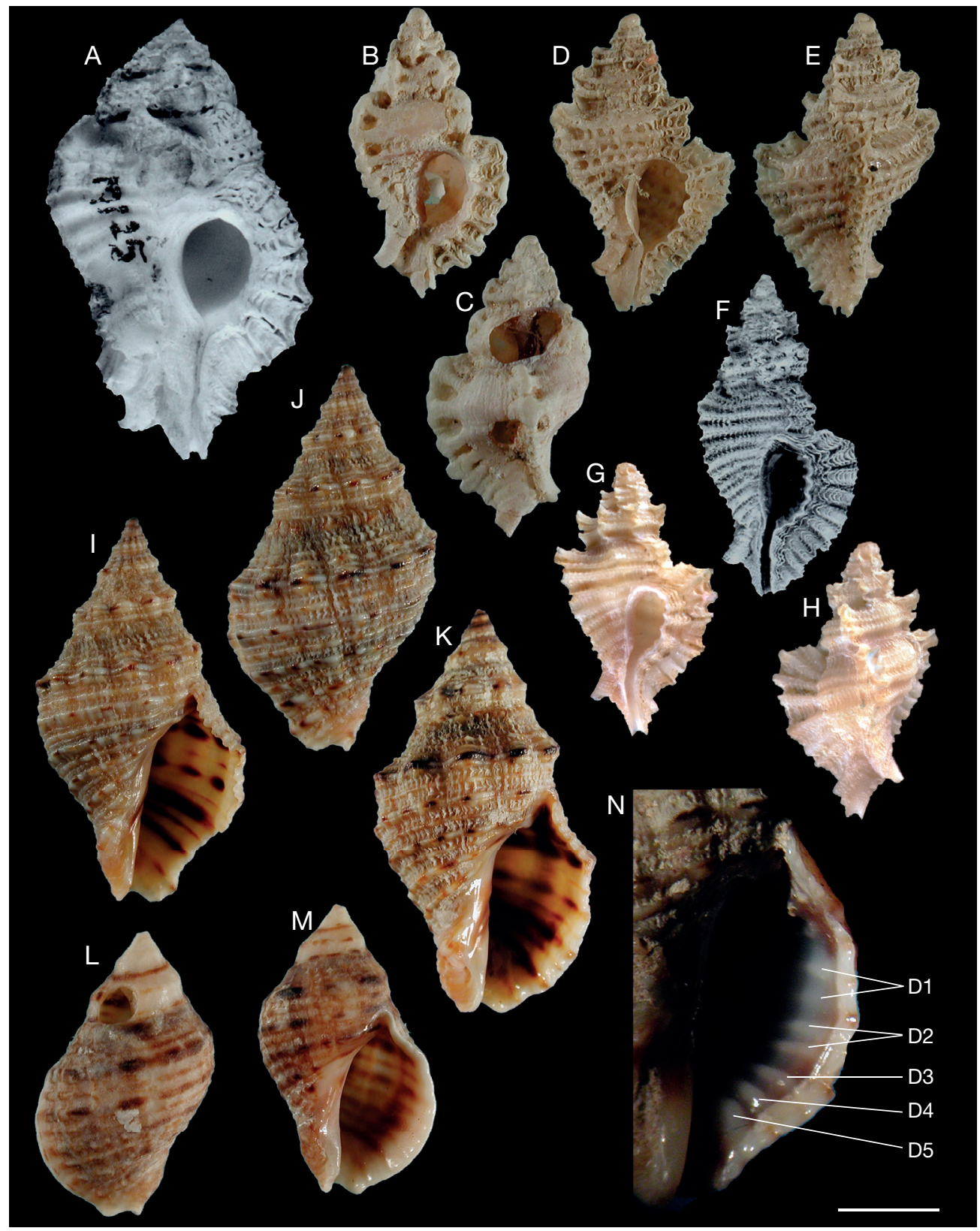

FIG. 6. - A, Favartia (F.) confusa (Brazier, 1877), holotype AMS C077183, $26.8 \mathrm{~mm}$ (scan of a white and black photograph); B-E, Favartia (Pygmaepterys) fournierae n. sp.; B, C, holotype MNHN 26518, 10.2 mm; D, E, paratype MNHN 26519, 8.4 mm; F, Favartia (Pygmaepterys) cracentis (Houart, 1996), holotype RMNH 57153, $11.8 \mathrm{~mm}$ (scan of black and white photograph); G, H, Favartia (Pygmaepterys) menoui (Houart, 1990), eastern New Caledonia, holotype MNHN 0193, 7 mm; I-N, Semiricinula bozzettii n. sp.; I, J, paratype MNHN 26524, 16 mm; K, paratype MNHN 26528, 17.2 mm; L, M, holotype MNHN 26522, 10.3 mm; N, apertural denticles, paratype MNHN 26525. Abbreviations: see Material and methods. Scale bar: N, $2 \mathrm{~mm}$. 
also differ in having somewhat higher and broader varices. They do not need to be compared further here.

Favartia (F) brevicula (Fig. 5M, N), a species occurring throughout the Indo-West Pacific, differs in having a comparatively larger, broader shell with more strongly shouldered teleoconch whorls, a less sloping shoulder ramp, higher varices and a more rounded aperture.

Favartia (F) confusa (Fig. 6A) from Queensland, Australia, differs in having a comparatively larger shell with more squamous varices, a less sloping shoulder ramp, relatively narrower spiral primary cords and a longer siphonal canal with the variceal wings almost extending to its tip.

Favartia (F.) eastorum (Fig. 5L) was described from Peak Island, Western Australia, and has not more recorded since. It resembles the new species but is distinctive in having a slightly higher and narrower shell with a less sloping shoulder ramp, a comparatively narrower aperture, a broader siphonal canal and slightly higher and narrower varices.

The holotype is not the best specimen but it has been chosen as the name-bearing type because it is associated with a molecular sequence.

Genus Favartia Jousseaume, 1880

Subgenus Pygmaepterys Vokes, 1978

TYPE SPECIES. - Murex alfredensis Bartsch, 1915, South Africa (by original designation).

\section{Favartia (Pygmaepterys) fournierae n. sp.} (Figs 1E; 3D, E; 6B-E; 7I, J)

Type Material. - Holotype MNHN 26518 and 7 paratypes MNHN 26518-26521, 1 paratype RH.

Type locality. - South Madagascar, West of Pointe Evatra, 24⒌ 59 'S, $47^{\circ} 05.4^{\prime} \mathrm{E}, 2-7 \mathrm{~m}$ (ATIMO VATAE: stn TB08).

Material examined. - ATIMO VATAE: stn

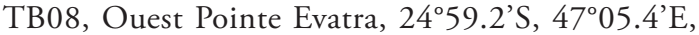
2-7 m, 1 lv (holotype MNHN 26518 = IM-200914264). - Stn DW3519, entre Lokaro et Ste Luce, $24^{\circ} 51.9^{\prime} \mathrm{S}, 47^{\circ} 28.0^{\prime} \mathrm{E}, 80-83 \mathrm{~m}, 2 \mathrm{lv}$ (1 paratype MNHN 26519, 1 paratype RH). - Stn DW3532, Nord de Sainte Luce, $24^{\circ} 39.4^{\prime} \mathrm{S}, 47^{\circ} 31.7^{\prime} \mathrm{E}, 86-87 \mathrm{~m}$, 1 dd. - Stn CP3603, SW Cap Sainte Marie, 2557.1'S, 44⒋67.'E, 62-63 m, 1 dd. - Stn DW3605, SW Cap Sainte Marie, $24^{\circ} 54.5^{\prime} \mathrm{S}, 44^{\circ} 51.0^{\prime} \mathrm{E}, 56-57 \mathrm{~m}, 3 \mathrm{dd}$ ad $\&$ juv (paratypes MNHN 26520). - Stn DW3606, SW Cap Sainte Marie, $25^{\circ} 48.4^{\prime}$ S, 44⒌ $51.1^{\prime} \mathrm{E}, 44-46 \mathrm{~m}$, 3 lv \& dd, ad \& juv (paratypes MNHN 26521). - Stn DW3607,

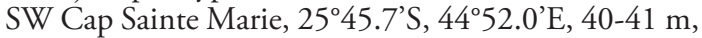
$1 \mathrm{dd}$, juv.

Distribution. - South Madagascar, live in 7-80 m, shells in 41-86 m.

ETymology. - At the request of Philippe Bouchet, this species is named after Laure Fournier, coordinator of marine biodiversity programmes at the Total Foundation. The Foundation has supported many MNHN expeditions since 2000, and was the main sponsor of the ATIMO VATAE expedition.

\section{DESCRIPTION}

Shell large for the subgenus, up to $8.4 \mathrm{~mm}$ in height at maturity. Height/width ratio 1.6-1.9. Biconical, broadly ovate, nodose and squamous. Subsutural ramp narrow, weakly sloping, weakly concave. Greyish white, light tan or reddish brown. Aperture similarly coloured. Protoconch milky white.

Spire high with 1.65-1.75 protoconch whorls and teleoconch up to 4.15 broad, angular, strongly shouldered, nodose whorls. Suture impressed. Protoconch small, whorls rounded, last part of last whorl minutely striate and punctuate; maximum width 650-750 $\mu \mathrm{m}$, height $600 \mu \mathrm{m}$. Terminal lip delicate, thin, weakly raised and weakly curved.

Axial sculpture of teleoconch whorls consisting of relatively strong, narrow, frondose varices. Other axial sculpture of low, flattened, broad growth lamellae or scales. First whorl with five or six varices, second with three to five varices, penultimate and last whorls with three varices. Spiral sculpture of high and low, weak and strong, rounded, squamous, primary and secondary cords. First whorl with low P1 and high P2, second whorl with P1P3, P2 broadest and highest, P3 partially covered by following whorl, third whorl with additional, occasional, narrow, low IP, fourth and last whorls with (IP), P1, P2, (s2), P3, P4, P5, (s5), P6, ADP, (MP). Spiral cords joined by low, flattened, broad growth lamellae or scales. IP, when present, very 


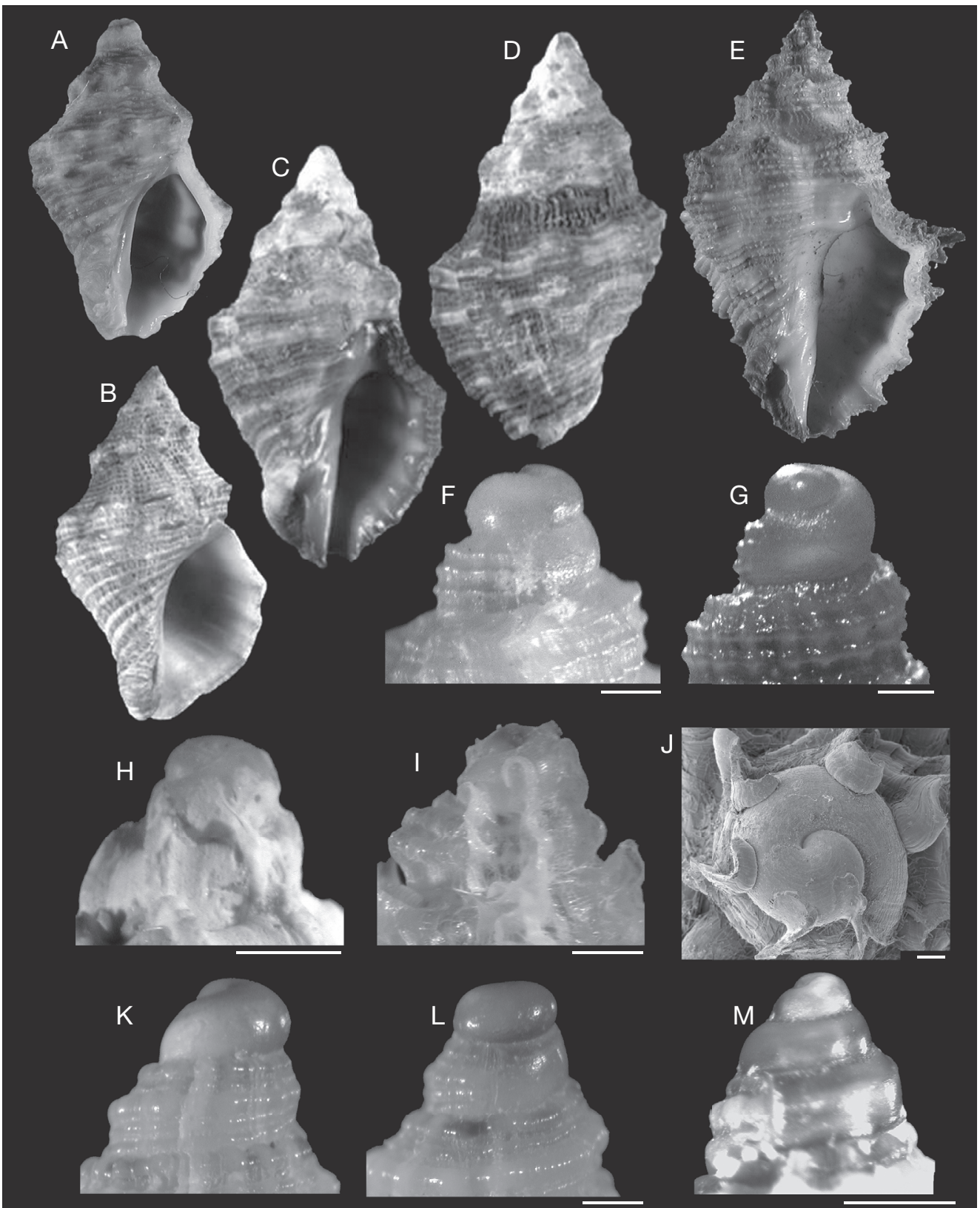

FIG. 7. - A, Phycothais botanica (Hedley, 1918), Australia, North NSW, Hastings Point, 12.4 mm, RH; B, Phycothais reticulata (Quoy \& Gaimard, 1832), Australia, Western Port, 16.8 mm, syntype MNHN 0927; C, D, Semiricinula muricoides (Blainville, 1832), New Zealand (erroneous), 23.4 mm, syntype MNHN 0163; E, Semiricinula turbinoides (Blainville, 1832), New Caledonia, 17.4 mm, RH; F-M, Protoconchs; F, Chicoreus (Triplex) kantori n. sp. (holotype), Scale bar: $500 \mu \mathrm{m}$; G, Naquetia manwaii n. sp. (holotype), Scale bar: $500 \mu \mathrm{m}$; H, Dermomurex (Dermomurex) charlesi n. sp. paratype MNHN 26514, Scale bar: 500 um; I, J, Favartia (Pygmaepterys) fournierae n. sp.; I, paratype MNHN 26520, Scale bar: 500 mm; J, paratype MNHN 26520, Scale bar: $100 \mu \mathrm{m}$; K, L, Semiricinula bozzettii n. sp. (ATIMO VATAE: stn BS12, MNHN), Scale bar: $500 \mu \mathrm{m}$; M, Semiricinula turbinoides (New Caledonia, RH), Scale bar: $500 \mu \mathrm{m}$. 
narrow, low, P1 broad, low, P2 broadest, high, s2, when present, narrow, rounded, $\mathrm{P} 3$ rounded or flat, P4-MP more conspicuous on varices, flat between varices, occasionally flat on varices.

Aperture moderately large, ovate. Columellar lip narrow, smooth, rim partially erect, adherent at adapical extremity. Anal notch shallow, broad. Outer lip weakly crenulated, smooth within or with very weak, low, elongate denticles. Siphonal canal short, narrow, strongly dorsally recurved at tip, narrowly open.

Operculum and radula unknown.

\section{REMARKS}

Three Pygmaepterys species are known from the studied area or nearby localities: $F$. (P.) alfredensis (Bartsch, 1915), the type species, from Port Alfred, South Africa, F. (P.) isabelae Houart \& Rosado, 2008 from Madagascar and Mozambique and $F$. (P.) maraisi (Vokes, 1978) from northern Transkei, South Africa. None of these species has a shell with three axial varices on the penultimate and last teleoconch whorls and they do not need to be compared here. F. (P.) alfredensis and $F(P$.$) isabelae$ have five narrow varices while $F(P$.) maraisi has six to eight varices on the last teleoconch whorl.

The Pygmaepterys species with three varices on the last teleoconch whorl are $F$. (P.) cracentis (Houart, 1996) from Indonesia, $F$ (P.) dondani (Kosuge, 1984) from the Philippines and $F$. (P.) menoui (Houart, 1990) from New Caledonia.

Favartia $(P$. dondani is a very different, larger species and does not need to be compared here.

Favartia (Pygmaepterys) cracentis (Fig. 6F) has a much narrower shell with more numerous axial varices on spire whorls: first and second whorl with seven ribs, third with six, penultimate with four or five and only the last whorl has three varices. The primary and secondary spiral cords are also more numerous than in $F$. (P.) fournierae $\mathrm{n}$. sp. and more regularly shaped with primary and secondary cords of almost similar size, with a total of 11 or 12 cords on the last teleoconch whorl.

Favartia (Pygmaepterys) menoui (Fig. 6G, H) is the most similar species, but it differs in having three varices only from the fourth teleoconch whorl instead of the second or third in $F$ (P.) fournierae n. sp., in having a different spiral sculpture mor- phology with broadly spaced P1 and P2 with an additional s1 between them, followed by a broad P3 and narrower P4, then s4, P5, P6, MP and ADP, and in having a comparatively smaller and narrower aperture.

The spiral cord morphology in $F$ (P.) fournierae n. sp., particularly the higher and broader second spiral cord (P2) as well as the axial, flattened growth lamellae or scales are reminiscent of Pterynotus concavopterus Kosuge, 1980 from the Philippines, a species that was doubtfully included in Timbellus de Gregorio, 1885 by Merle et al. (2011). The similarities between $P$. concavopterus and $F(P$.) fournierae n. sp. and other Pygmaepterys species are intriguing. The shell morphology of $P$. concavopterus is certainly more similar to muricopsine species than to any Pterynotus Swainson, 1833 or Timbellus species. Molecular analyses and study of the radula are needed to confirm the probable new classification of this species, till now only known from the Philippines.

Subfamily RAPANINAE Gray, 1853

Genus Semiricinula Martens, 1904

Type SPeCIES. - Purpura muricina Blainville, 1832 (Indo-West Pacific) (by original designation).

\section{REMARKS}

There are currently nine or ten species of Semiricinula occurring in the Indo-West Pacific (Claremont et al. 2013a). Only two, S. turbinoides (Blainville, 1832) and T. tricolorata Bozzetti, 2010, a probable Semiricinula, live off Madagascar. The genus occurs throughout the Indo-West Pacific, from South Africa (Houart et al. 2011: 259) to Japan (Tsuchiya 2000: 397, pl. 97, figs 173 [as Thais muricata] and 176 [as Thaissp.]; 399, pl. 198, fig. 180 [as Thais squamigera]) and French Polynesia (Houart \& Tröndlé 2008).

Semiricinula bozzettii n. sp. (Figs 1F; 3C; 6I-N; 7K, L; 8C-E)

TYPE MATERIAL. - Holotype MNHN 26522, 11 paratypes MNHN 26523-26528, 3 RH. 

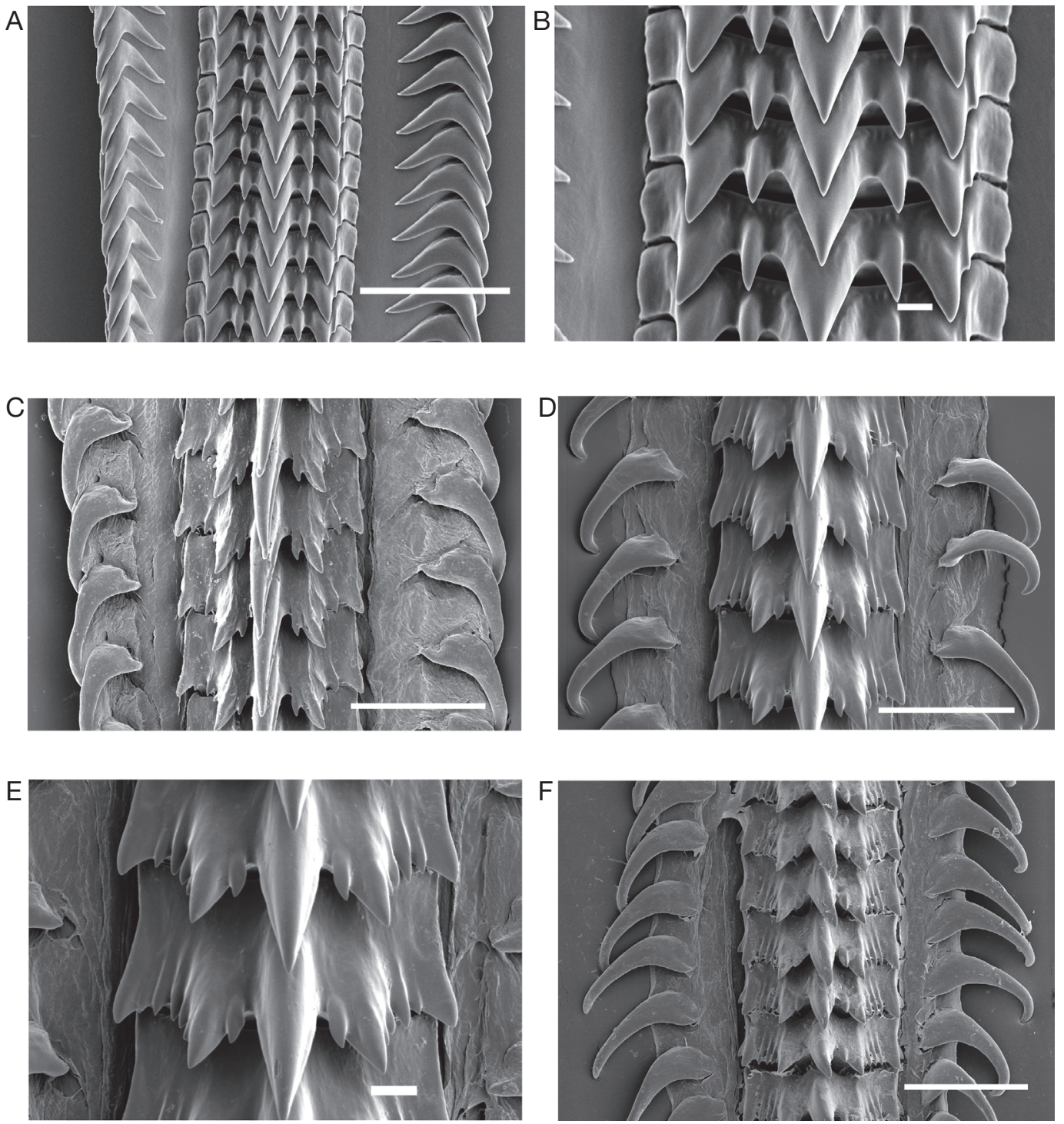

FIG. 8. - Radulae; A, B, Naquetia manwaii n. sp., holotype MNHN 26506, A, Scale bar: 100 m; B, Scale bar: $10 \mu$; C-E, Semiricinula bozzettii n. sp.; C, paratype MNHN 26527, Scale bar: 50 um; D, E, paratype MNHN 26526; D, Scale bar: $50 \mu \mathrm{m}$; E, Scale bar: $10 \mu \mathrm{m}$; F, Semiricinula turbinoides (Blainville, 1832), Balicasag, Philippines, RH, Scale bar: $60 \mu \mathrm{m}$.

TYPE LOCALITY. - South Madagascar, Îlot de Lokaro,

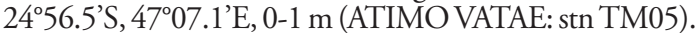

MATERIAL EXAMINED. - ATIMO VATAE: stn BM01, Plage de Lavanono, $25^{\circ} 25.2^{\prime} \mathrm{S}, 44^{\circ} 56.3^{\prime} \mathrm{E}, 0-1 \mathrm{~m}, 1 \mathrm{lv}$ (paratype MNHN 26524 = IM-2009-14735). - Stn TM02, Cap Ranavalona, $25^{\circ} 04.3^{\prime} \mathrm{S}$, 46⒌7.7'E, 0-1 m, $1 \mathrm{lv}$,

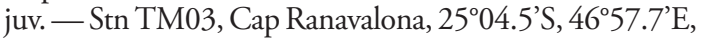

0-1 m, 1 lv, juv. — Stn BS05, Cap Sainte Marie, 2535.4'S, 4508.0'E, $12 \mathrm{~m}, 1 \mathrm{lv}$ (IM-2009-22459 BOLD ID BOMGA012-13, GenBank accession number for COI gene KC860509). - Stn TM05, Îlot de Lokaro, 24은.5'S, $47^{\circ} 07.1^{\prime} \mathrm{E}, 0-1 \mathrm{~m}, 2 \mathrm{lv}$ (holotype MNHN $26522 \mathrm{se}-$ quenced as IM-2009-22436 BOLD ID BOMGA008-13, GenBank accession number for COI gene KC860510), paratype MNHN 26523 sequenced as IM-2009-22490 
BOLD ID BOMGA001-13, GenBank accession number for COI gene KC860508). - Stn BM07, Est du Cap Malaimpioka, $25^{\circ} 21.5^{\prime} \mathrm{S}, 44^{\circ} 50.0^{\prime} \mathrm{E}, 0-1 \mathrm{~m}, 1 \mathrm{lv}$ (paratype MNHN 26525). - Stn TS11, Cap Ranavalona, Bevava, $25^{\circ} 04.4^{\prime} \mathrm{S}, 46^{\circ} 57.1^{\prime} \mathrm{E}, 4-5 \mathrm{~m}, 1 \mathrm{dd}$, juv. - Stn BS12, Rocher de l'Albatros, $2^{\circ} 28.6^{\prime} \mathrm{S}, 44^{\circ} 56.8^{\prime} \mathrm{E}, 12 \mathrm{~m}, 2 \mathrm{dd}$, juv. - Stn TP15, Baie de Fort-Dauphin, $25^{\circ} 00.06^{\prime} \mathrm{S}$, $47^{\circ} 00.0^{\prime} \mathrm{E}, 16-18 \mathrm{~m}, 1 \mathrm{lv}$ (IM-2009-22447 BOLD ID BOMGA013-13, GenBank accession number for COI gene KC860512) - Stn BV16, devant Lavanono, $25^{\circ} 25.6^{\prime} \mathrm{S}, 4^{\circ} 55.9^{\prime} \mathrm{E}, 9 \mathrm{~m}, 1 \mathrm{lv}$. - Stn TM19, Sainte Luce, $24^{\circ} 47.1^{\prime} \mathrm{S}, 47^{\circ} 11.9^{\prime} \mathrm{E}, 0-1 \mathrm{~m}, 3 \mathrm{lv}$ (paratypes MNHN 26526). - Stn TP19, devant plage d'Ambinanibe, $25^{\circ} 04.4-7^{\prime} \mathrm{S}, 46^{\circ} 55.3-56.3^{\prime} \mathrm{E}, 19-26 \mathrm{~m}$, 1 dd. - Stn TS20, "entrée "Lac" de Mananivo, 2456.0'S, $47^{\circ} 06.7^{\prime} \mathrm{E}, 3 \mathrm{~m}, 1 \mathrm{lv}$ - - Stn TM21, Baie des Galions, $25^{\circ} 08.9^{\prime} \mathrm{S}$, $46^{\circ} 45.4^{\prime} \mathrm{E}, 0-1 \mathrm{~m}, 6 \mathrm{lv}$ (3 paratypes MNHN 26527, 3 paratypes RH). - Stn TP21, Fausse Baie des Galions, 2503.3'S, 46 59.1'E, 23-25 m, 1 dd, juv. - Stn BP23, secteur de Lavanono, $25^{\circ} 26.4-8^{\prime} S$, 44ํ56.1-3'E, 6-9 m, 1 lv (IM-2009-22466 BOLD ID BOMGA003-13, GenBank accession number for COI gene KC860511) and 3 dd. - Stn BP24, secteur de Lavanono, 25⒉ $27.1^{\prime} \mathrm{S}, 44^{\circ} 56.2^{\prime} \mathrm{E}, 13 \mathrm{~m}, 2 \mathrm{lv}$ (paratypes MNHN 26528). - Stn BP33, secteur de Lavanono, 2525.80-8'S, 44'55.7-8'E, 11-13 m, 1 dd. - Stn TA59, Baie des Galions, $25^{\circ} 09.1^{\prime} \mathrm{S}, 46^{\circ} 45.4^{\prime} \mathrm{E}$ (no other data), $1 \mathrm{dd}$.

Distribution. - South Madagascar, live in 0-1 m, intertidal, shells in 5-23 m.

ETYMOLOGY. - The species is named after Luigi Bozzetti, of Milano, the pioneer of molluscan exploration in southern Madagascar, and author of many new species, including of Muricidae. Luigi joined the ATIMO VATAE expedition field party in Fort-Dauphin.

\section{DESCRIPTION}

Shell small for the genus, up to $17.4 \mathrm{~mm}$ in height at maturity (paratype MNHN). Height/width ratio 1.7-1.9. Lanceolate, narrowly-ovate, nodose and squamous, lightly built. Subsutural ramp broad, strongly sloping and strongly concave.

Light tan, dark tan or greyish with dark brown blotches on nodes of primary spiral cords, some light brown blotches on secondary cords. Shell lighter coloured between primary spiral cords. Columellar lip greyish or yellowish brown, dark brown on and between columellar folds. Inner side of outer lip light brown, dark brown between apertural denticles.

Spire high with 1.75 protoconch whorls. Teleoconch up to five convex, weakly angular, strongly shouldered, squamous whorls. Suture adpressed, partially obscured by small axial lamellae of next whorl. Protoconch moderately large, whorls rounded, smooth; maximum width $800 \mu \mathrm{m}$, height $900 \mu \mathrm{m}$. Terminal lip narrow, almost straight.

Axial sculpture of teleoconch whorls consisting of very low, broad, rounded ribs, narrower on two first teleoconch whorls. Other axial sculpture of numerous, high, thin, growth lamellae. First and second whorls with 13 ribs, third with 11 or 12 ribs, fourth with 10, last with 9 ribs. Spiral sculpture of high, strong, rounded, narrow, nodose primary and secondary cords and lower, narrower, squamous threads. First teleoconch whorl with SP, IP, P1, s1, (P2). P2 covered partially or completely by next whorl, second whorl with SP, IP, P1, (t), s1, P2, third whorl of a juvenile specimen with SP, adis, IP, abis, P1 split, t, s1, t2, P2, s2, t, P3, s3, P4, s4, P5, P6, fourth whorl of a juvenile with SP, adis, IP, abis, P1 split, t, s1, P2, s2, P3, s3, P4, s4, P5, P6. Last whorl with SP, $t$, adis, IP, abis, P1 split, t, s1, t, P2, t, s2, t, P3, t, s3, t, P4, s4, P5, (s5), P6, (s6), and occasional fine threads between secondary and primary spiral cords. Crossing of axial ribs and primary spiral cords giving rise to broad, moderately high nodes. Crossing of axial growth lamellae with secondary cords and threads giving a reticulate appearance to the shell.

Aperture moderately large, ovate. Columellar lip narrow, with two elongate, weak, oblique folds centrally, rim completely adherent, broadly expanded abapically. Occasionally with weak parietal tooth at adapical extremity. Anal notch deep, narrow. Outer lip weakly erect, thin, with weak or very weak, elongate denticles within: D1 split, D2 split, D3, D4, D5 (Fig. 6N). Denticles increasing in strength up to D4; D5 very shallow, almost indistinguishable. Siphonal canal very short, broad, straight, broadly open.

Operculum light brown, thin, D-shaped, tapered adapically, with lateral nucleus in lower right. Attached surface with few growth lines and broad, thin, callused rim.

Radula (Fig. 8C-E) with a broad, long, elongate, central cusp, a twice shorter, broad, lateral cusp on each side with a short inner and outer lateral denticle on its base, two or three short marginal 
denticles and a broad, moderately high marginal cusp. Lateral tooth sickle shaped, narrow, with a broader base.

\section{REMARKS}

The new species described here is included in Semiricinula because of the similar radular and operculum morphologies but also because of identical shell morphologies, especially the squamous shell structure, the typical, deep anal notch, and the two narrow columellar folds. The radula of $S$. turbinoides is illustrated (Fig. 8F) to show the similarities between the two species.

Semiricinula bozzettii n. sp. differs from S. turbinoides (Fig. 7E) in having a lighter, more delicate shell with more numerous axial ribs, nine or ten on penultimate and last whorls vs seven in $S$. turbinoides, much narrower primary spiral cords, split apertural denticles and chiefly, in having a very different protoconch of 1.75 rounded whorls (Fig. $7 \mathrm{~K}$, L) vs 2.5-3 whorls with a duplicate narrow keel on the last whorl in S. turbinoides. The protoconch also lacks a sinusigeral notch (Fig. 7M).

The status of Thais tricolorata Bozzetti, 2010 will be discussed in an upcoming paper in progress. However, S. bozzettii n. sp. differs from T. tricolorata in the same ways that it differs from $S$. turbinoides.

Semiricinula bozzettii n. sp. can also be compared with S. muricoides (Blainville, 1832) (Fig. 7C, D), which has not been recorded from Madagascar and which also has a paucispiral protoconch of 1.75 to 2 rounded whorls. However, S. bozzettii n. sp. differs from $S$. muricoides in having a smaller, more delicate shell with much narrower primary spiral cords, a narrower anal notch, split apertural denticles and more numerous axial ribs.

Because of its reticulate shell morphology, Semiricinula bozzettii $\mathrm{n}$. sp. could also be considered as a Phycothais Tan, 2003 species. Phycothais was originally described by Tan (2003: 956) to include two intertidal Australian species: P. reticulata (Quoy \& Gaimard, 1832), which occurs from New South Wales to Western Australia, including Tasmania, and P. botanica (Hedley, 1918), known from Queensland to Tasmania. The shells are small, less than $20 \mathrm{~mm}$ in length with a paucispiral protoconch and a typical rapanine radula.
A third species of Phycothais, P. texturata (E. A. Smith, 1904) was recently recorded by Houart et al. (2011).

The shells also have a typical reticulate or cancellate sculpture due to the numerous axial growth lamellae, more obvious between than on the spiral cords.

Semiricinula bozzettii $\mathrm{n}$. sp. is similar to $P$. reticulata (Fig. 7B) but differs in having a slightly narrower shell with a relatively higher spire, a different, narrower and deeper anal notch, a more obvious parietal tooth, and a folded columella, which is smooth in P. reticulata. It differs also from $P$. botanica (Fig. 7A) in having a higher spire, a slightly less shouldered shell, a different, narrower and deeper anal notch, a folded columellar lip and also in having somewhat narrower primary spiral cords.

Finally, Semiricinula bozzettii n. sp. differs in shell characters from $P$. texturata in the same way that it differs from $P$. reticulata but also in having secondary and tertiary cords of similar strength in $P$. texturata vs of different strength in S. bozzettii n. sp.

The holotype is not the best specimen, but it has been chosen as the name-bearing type because it is associated with a molecular sequence

\section{Acknowledgements}

The ATIMO VATAE expedition to South Madagascar (Principal Investigator, Philippe Bouchet) was part of a cluster of Mozambique-Madagascar expeditions funded by the Total Foundation, Prince Albert II of Monaco Foundation, and Stavros Niarchos Foundation under "Our Planet Reviewed", a joint initiative of MNHN and Pro Natura International (PNI) in partnership with Institut d'Halieutique et des Sciences Marines, University of Toliara (IH.SM) and the Madagascar bureau of Wildlife Conservation Society (WCS). The trawler "Nosy Be 11" - used to sample the continental shelf and upper slope - was chartered from Société des Pêcheries de Nosy Bé (Groupe Unima) under the supervision of Theo Martin; Jean-François Barazer coordinated the deployment of the sampling gears on board.

The molecular sequences were obtained by Céline Bonillo in the Service de Systématique Moléculaire of the MNHN, and we also thank Nicolas Puil- 
landre who placed them in a tree and commented on their significance for us.

We are also grateful to Anders Warén (Natural History Museum, Stockholm, Sweden) and Yuri Kantor (A. N. Severtsov Institute of Ecology and Evolution, Russian Academy of Sciences, Moscow, Russia) for preparation of, and SEM work on the radula; to P. Maestrati (MNHN) for SEM of the protoconch of Favartia (P.) fournierae n. sp.; to Gilberto Marani (MNHN) for the distribution maps; to John Wolff (Lancaster, Pennsylvania, USA), for linguistic help to RH; to Rob. Cowie (University of Hawaii, USA) for useful comments on the manuscript; and to Philippe Bouchet for his continuous help in many ways during the finalizing of this paper.

We also acknowledge the help of Alwyn Marais (Centre for Molluscan Studies, South Africa) for the image of the holotype of Chicoreus (T.) zululandensis; of Winston F. Ponder and Ian Loch (Australian Museum, Sydney, Australia) for the loan of the holotype of Favartia confusa; and of Emily H. Vokes (Professor Emeritus, Tulane University) for the permission to use her photographs. We are also grateful to the reviewers for their helpful comments.

\section{REFERENCES}

Barco A., Claremont M., Reid D. G., Houart R., Bouchet P., Williams S. T., Cruaud C., Couloux A. \& Oliverio M. 2010. - A molecular phylogenetic framework for the Muricidae, a diverse family of carnivorous gastropods. Molecular Phylogenetics and Evolution 56: 1025-1039.

BouCHET P. 1999. - A new Lyria (Gastropoda, Volutidae) from southeastern Madagascar. The Nautilus 113 (1): 1-3.

BozzetTi L. 2006. - A new species of Fusinus (Mollusca: Neogastropoda: Fasciolariidae) from Southern Madagascar. Visaya 1 (6): 51-53.

BozzetTi L. 2008. — Pleuroploca manuelae (Gastropoda: Neogastropoda: Fasciolariidae) a new species from Southern Madagascar. Malacologia Mostra Mondiale 58: 8-11.

Claremont M., Williams S. T., Barraclough T. G. \& REID D. G. 2011a. - The geographic scale of speciation in a marine snail with high dispersal potential. Journal of Biogeography 38: 1016-1032.
Claremont M., Reid D. G. \& Williams S. T. 2011b. - Evolution of corallivory in the gastropod genus Drupella. Coral Reefs 30: 977-990.

Claremont M., Vermeij G. J., Williams S. T. \& REID D. G. 2013a. - Global phylogeny and new classification of the Rapaninae (Gastropoda: Muricidae), dominant molluscan predators on tropical rocky seashores. Molecular Phylogenetics and Evolution 66: 91-102.

Claremont M., Houart R., Williams S. T. \& REID D. G. 2013b. - A molecular phylogenetic framework for the Ergalataxinae (Neogastropoda: Muricidae). Journal of Molluscan Studies 79: 19-29.

HOUART R. 1992. — The genus Chicoreus and related genera (Gastropoda: Muricidae) in the Indo-West Pacific. Mémoires du Muséum national d'Histoire naturelle (A) 154: 1-188.

HouART R. \& TRÖNDLÉ J. 2008. — Update of Muricidae (excluding Coralliophilinae) from French Polynesia with description of ten new species. Novapex 9(2-3): 53-93.

Houart R., Kilburn R. N. \& Marais A. P. 2011. - Muricidae, in Marais A. P \& SeCCOMBE A. D., Identification Guide to the Seashells of South Africa. Vol. 1: 177-270. Centre for Molluscan Studies, Groenkloof, $376 \mathrm{p}$.

KEEN M. 1971. - Two new supraspecific taxa in the Gastropoda. The Veliger 13: 296.

KooL S. P. 1993. - Phylogenetic analysis of the Rapaninae (Neogastropoda: Muricidae). Malacologia 35 (2): 155-259.

Lutjeharms J. R. E. \& MACHU E. 2000. — An upwelling cell inshore of the East Madagascar Current. Deep-Sea Research I, 47: 2405-2411.

MERLE D. 1999. - La radiation des Muricidae (Gastropoda: Neogastropoda) au Paléogène: approche phylogénétique et évolutive. Muséum national d'Histoire naturelle, Paris: i-vi, 499 p.

MERLE D. 2001. - The spiral cords and the internal denticles of the outer lip in the Muricidae: terminology and methodological comments. Novapex 2 (3): 69-91.

Merle D., Garrigues B. \& Pointier J. P. 2011. — Fossil and Recent Muricidae of the World. Part Muricinae. Conchbooks, Hackenheim, 648 p.

Piton B. \& Laroche J. 1993. — Quelques caractéristiques hydroclimatiques du sud de Madagascar. Bulletin Océanographie et Pêches 37: 46-54.

Spalding M. D., Fox H. E., Allen G. R., Davidson N., Ferdaña Z. A., Finlayson M., Halpern B. S., Jorge M. L A., Lombana A., Lourie S. A., MarTin K. D., McManus E., Molnar J., Recchia C. A. \& ROBERTSON J. 2007. - Marine ecoregions of the world: A bioregionalization of coastal and shelf areas. BioScience 57 (7): 573-583.

TAN K. S. 2003. - Phylogenetic analysis and taxonomy of some southern Australian and New Zealand Muri- 
cidae (Mollusca: Neogastropoda). Journal of Natural History 37: 911-1028.

TsUCHIYA K. 2000. - Muricidae, in OKUTANI T. (ed.), Marine Mollusks in Japan. Tokai University Press, Tokyo: 364-421.

VOKES E. H. 1964. - Supraspecific groups in the subfamilies Muricinae \& Tritonaliinae (Gastropoda: Muricidae). Malacologia 2 (1): 1-41.
VOKES E. H. 1971a. - Catalogue of the genus Murex Linné (Mollusca: Gastropoda, Muricinae, Ocenebrinae. Bulletin of American Paleontologist 61 (268): 1-141.

VOKES E. H. 1971b. - The geologic history of the Muricinae and the Ocenebrinae. The Echo 4: 37-54.

VOKES E. H. 1985. — The genus Dermomurex (Mollusca: Gastropoda) in Australia. Journal of the Malacological Society of Australia 7 (1-2): 45-65.

Submitted on 27 March 2013; accepted on 20 September 2013; published on 27 December 2013. 